\title{
Pengaruh Model Pembelajaran Thinking Aloud Pair Problem Solving Terhadap Hasil Belajar IPA Fisika Siswa
}

\author{
Rina Mariyana ${ }^{1)}$, Sukainil Ahzan ${ }^{2^{*}}$, Baiq Azmi Sukroyanti ${ }^{3)}$ \\ ${ }^{1,2 \& 33}$ Program Studi Pendidikan Fisika, FPMIPA, IKIP Mataram \\ *Email:sukainilahzan@ikipmataram.ac.id
}

\section{Article History}

Received: April 2018

Reviewed: May 2018

Published: June 2018

Key Words

Learning Model Thinking

Aluod Pair Problem

Solving;

Learning Outcomes;

Problem Solving

\section{Sejarah Artikel}

Diterima: April 2018

Direviu: Mei 2018

Dipublikasi: Juni 2018

Kata Kunci:

Model Pembelajaran

Thinking Aluod Pair

Problem Solving;

Hasil Belajar;

Pemecahan Masalah

How to cite this article?

\begin{abstract}
[Title: The Effect of Thinking Aloud Pair Problem Solving Learning Model Toward Student Physics Science Learning Outcomes]. This study aims to determine the effect of learning model Thinking Aloud Pair Problem Solving on the results of science learning Physics Class VIII SMPN 6 Praya Timur. This research is a quasi-experimental research with Posttes -Only Control Design research design. The samples of this research are taken using Purposive Sampling technique with class VIIIc as the experiment class is 24 students and VIIId as the control class is 24 students. The instrument used in the form of test description in the form of 10 questions that are tailored to the learning indicators. The result of data analysis obtained using t-test at 5\% significant level shows that the value of $t_{\text {count }}>t_{\text {table }}\left(t_{\text {count }}=0.634 \& t_{\text {table }}=0201\right)$ then $\mathrm{Ha}$ in receipt. so it can be concluded that the learning model Thinking Aloud Pair Problem Solving can affect the results of science learning Physics Student.
\end{abstract}

\begin{abstract}
Abstrak
Penelitian ini bertujuan untuk mengetahui pengaruh model pembelajaran Thinking Aloud Pair Problem Solving terhadap hasil belajar IPA Fisika Siswa Kelas VIII SMPN 6 Praya Timur. Penelitian ini merupakan penelitian eksperimen semu dengan desain penelitian Posttes Only Control Design. Dimana sampel penelitian ini diambil menggunakan teknik Purposive Sampling dengan kelas VIIIc sebagai kelas eksperimen berjumlah 24 siswa dan VIIId sebagai kelas kontrol berjumlah 24 siswa. Instrumen yang di gunakan berbentuk tes uraian berupa 10 soal yang disesuaikan dengan indikator pembelajaran. Hasil analisis data yang diperoleh menggunakan uji-t pada taraf signifikan $5 \%$ menunjukan nilai $t_{\text {hitung }}>t_{\text {tabel }}\left(t_{\text {hitung }}=\right.$ 0.634 dan $\left.t_{\text {tabel }}=0.201\right)$ maka Ha diterima, sehingga dapat disimpulkan bahwa model pembelajaran Thinking Aluod Pair Problem Solving dapat berpengaruh terhadap hasil belajar IPA Fisika Siswa.
\end{abstract}

Mariyana, R., Ahzan S., Sukroyanti, B., A. (2018). Pengaruh Model Pembelajaran Thinking Aloud Pair Problem Solving Terhadap Hasil Belajar IPA Fisika Siswa. Lensa: Jurnal Kependidikan Fisika, 6(1), 18-22.

\section{PENDAHULUAN}

Menurut parlemen 22 tahun 2006 tentang Standar isi untuk Satuan Pendidikan Dasar dan Menengah, salah satu tujuan pembelajaran di SMP/MTs adalah mengembangkan kemampuan bernalar dalam berpikir analisis induktif dan deduktif dengan menggunakan konsep dan prinsip IPA untuk menjelaskan berbagai peristiwa alam dan menyelesaikan masalah baik kualitatif dan kuantitatif. Jadi banyak hal dalam kehidupan seahari-hari yang dapat di selesaikan dengan prinsip dan konsep IPA.

Fisika adalah bagian dari Ilmu Pengetahuan Alam (IPA) yang pada hakikatnya merupakan kumpulan pengetahuan yang berupa fakta, konsep, prinsip, hukum, teori dan model yang biasa di sebut produk. Bidang ilmu fisika juga merupakan serangkaian proses ilmiah untuk mendapatkan fakta, jadi yang paling penting dalam fisika adalah proses dalam pembelajaran fisika itu sendiri (Awal, 2013). 
Kenyataan di lapangan bahwa hasil belajar siswa pada pembelajaran IPA Fisika tidak memenuhi standar nilai yang sudah di tentukan atau masih di bawah nilai Kriteria Ketuntasan Minimum.

Hasil observasi awal yang telah di lakukan di SMPN 6 Praya Timur menunjukan bahwa hasil belajar siswa pada mata pelajaran IPA masih tergolong rendah. Hal ini di tunjukan pada nilai rata-rata ulangan harian siswa pada kelas VIII C dan VIII D yang berada di bawah Kriteria Ketuntasan Minimum (KKM). Berikut adalah tabel hasil belajar IPA siswa yang di lakukan pada dua kelas di SMPN 6 Praya Timur tahun pelajaran 2016/2017.

Tabel 1. Nilai Hasil Tes Belajar Awal IPA Siswa di SMPN 6 Praya Timur Tahun Pelajaran 2016/2017.

\begin{tabular}{lllll}
\hline No & Kelas & Jumlah Siswa & Nilai Rata - rata & KKM \\
\hline 1. & VIII C & 24 Orang & 53.91 & 70 \\
\hline 2. & VIII D & 24 Orang & 58.13 & 70 \\
\hline
\end{tabular}

Berdasarkan tabel di atas, peneliti mencoba mengukur hasil belajar IPA awal siswa pada dua kelas di SMPN 6 Praya Timur. Hasil belajar awal yang di dapatkan memebuktikan bahwa hasil belajar IPA siswa pada dua kelas masih berada di bawah standar KKM. Hal ini menunujukan hasil belajar siswa pada mata pelajaran IPA Fisika masih tergolong rendah.

Thinking Aloud artinya berpikir yang diverbalkan, Pair artinya berpasangan dan Problem Solving artinya pemecahan atau penyelesaian masalah. Jadi Thinking Aloud Pair Problem Solving (TAPPS) dapat diartikan sebagai teknik berpikir yang diverbalkan secara berpasangan dalam menyelesaikan masalah. TAPPS merupakan salahsatu metode pembelajaran yang dapat menciptakan kondisi belajar aktif. Sehingga model TAPPS memberikan tantangan kepada siswa untuk belajar dan berpikir sendiri.

Model ini pertamakali diperkenalkan oleh Claparade, yang kemudian digunakan oleh Bloom dan Bloder untuk meneliti proses pemecahan masalah pada siswa SMA. Art Whimbey dan Jack lochhead telah mengembangkan metode ini pada pengajaran matematika dan fisika yang merupakan ruang lingkup dari pelajaran IPA.

Pada model TAPPS, siswa di bagi menjadi beberapa tim, setiap tim terdiri dari dua orang. Satu orang siswa berperan sebagai problem solver dan satu orang lagi sebagai listener.

Tabel 2. Tahapan TAPPS

\begin{tabular}{|c|c|}
\hline Tahapan & Kegiatan Guru Dan Siswa \\
\hline $\begin{array}{l}\text { Tahap 1 } \\
\text { Orientasi } \\
\text { masalah }\end{array}$ & $\begin{array}{l}\text { - Dengan tanya jawab guru menjelaskan materi yang akan } \\
\text { di bahas } \\
\text { - } \quad \text { Siswa dan guru sama - sama membahas contoh soal. } \\
\text { - Guru memberikan kesempatan kepada siswa kalau belum } \\
\text { memahami }\end{array}$ \\
\hline $\begin{array}{l}\text { Tahap } 2 \\
\text { Mengorganikan siswa untuk } \\
\text { belajar }\end{array}$ & $\begin{array}{l}\text { Guru membagikan siswa dalam } 12 \text { tim, setiap tim terdiri } \\
\text { dari } 2 \text { orang. Dimana mereka bekerja saling berpasangan } \\
\text { satu pihak (siswa A) problem solver dan satu pihak (siswa } \\
\text { B) listener. }\end{array}$ \\
\hline $\begin{array}{l}\text { Tahap } 3 \\
\text { Membimbing penyelidikan } \\
\text { individual dan kelompok }\end{array}$ & $\begin{array}{l}\text { - Guru memberikan sebuah LKS yang berisi masalah- } \\
\text { masalah yang harus dipecahkan (LKSterlampir). }\end{array}$ \\
\hline $\begin{array}{l}\text { Tahap } 4 \\
\text { Mengembangkan dan } \\
\text { menyajikan hasil diskusi }\end{array}$ & $\begin{array}{l}\text { - Siswa menyelesaikan masalah secara bergantian guru } \\
\text { hanya sebagai fasilitator. Sambil berkeliling guru } \\
\text { mengawasi jalannya proses diskusi dan membantu jika } \\
\text { ada siswa yang mengalami kesulitan. } \\
\text { - Soal nomor } 1 \text { siswa A sebagai problem solver dan siswa B } \\
\text { sebagai listener. } \\
\text { - Jika satu masalah terselesai siswa bergantian tugas soal } \\
\text { nomor } 2 \text { siswa B sebagai problem solver dan siswa A } \\
\text { sebagai listener }\end{array}$ \\
\hline Tahap 5 & - Guru meminta \\
\hline
\end{tabular}




\begin{tabular}{lrl}
\hline $\begin{array}{l}\text { Menganalisis } \\
\text { mengevaluasi } \\
\text { pemecahan masalah }\end{array}$ & $\begin{array}{r}\text { dan } \\
\text { proses }\end{array}$ & $\begin{array}{l}\text { memperesentasikan hasil diskusi mereka, jika ada } \\
\text { kekeliruan guru meluruskannya }\end{array}$ \\
\hline
\end{tabular}

Belajar sebagaimana yang di sebutkan Slameto (2010) adalah suatu proses usaha yang di lakukan seseorang untuk memperoleh suatu perubahan tingkah laku yang baru secara keseluruhan, sebagai hasil pengalamannya sendiri dengan interaksi dengan lingkungan. Perubahan sebagai hasil dari proses belajar dapat di tunjukan dalam berbagai bentuk seperti berubahnya pengetahuan, pemahaman sikap, dan tingkah laku, keterampilan, kecakapan dan kemampuan, daya kreasi dan daya penerimaannya serta aspek - aspek lain yang ada pada individu.

Menurut Dimayati dan Mudjiono hasil belajar merupakan hal yang dapat di pandang dari dua sisi yaitu sisi siswa dan sisi guru.Menurut Hamdani, hasil belajar di bidang pendidikan adalah hasil dari pengukuran terhadap siswa yang meliputi 3 perilaku yaitu perilaku kognitif (pemahaman), afektif (sikap), dan psikomotor.

\section{METODE}

Jenis penelitian ini adalah penelitian eksperimen karena peneliti ingin mengetahui pengaruh terhadap perlakuan yang diberikan. Menurut Sugiyono (2010), penelitian eksperimen adalah penelitian yang digunakan untuk melihat pengaruh perlakuan tertentu terhadap variabel variabel yang diteliti dan dalam kondisi yang di kendalikan.

Secara rinci prosedur penelitian di tiap- tiap tahap di jabarkan sebagai berikut. Tahap persiapan kegiatan yang dilakukan pada tahap ini adalah observasi lapangan, menyusun proposal, menysun perangkat pembelajarn. Tahap perlaksanaan, adapun yang dilakukan dalam kegiatan ini yaitu perlakuan terhadap sampel penetian sesuai dengan yang sudah disiapkan pada tahap persiapan. Tahap akhir yaitu tahap dimana yang dilakukan adalah menganalisis data dan membuat kesimpulan.

\section{HASIL DAN PEMBAHASAN}

Nilai rata - rata pada kedua kelas, kelas eksperimen memepunyai nilai rata - rata 74.38 dengan kategori baik (B) lebih tinggi dari pada nilai rata - rata kelas kontrol yaitu 71.90 dengan kategori cukup baik (CB) seperti disajikan pada Tabel 3.

Tabel 3 Data hasil Posttes belajar IPA Fisika siswa

\begin{tabular}{ccc}
\hline Kelas & Nilai Rata - Rata & Kategori \\
\hline Eksperimen & 74.38 & B \\
\hline Kontrol & 71.90 & CB
\end{tabular}

Data dikatakan homogen jika $F_{\text {hitung }}<F_{\text {tabel }}$ pada taraf signifikan $5 \%$. Berdasarkan menunjukan bahwa $F_{\text {hitung }}=1,2<F_{\text {tabel }}=2,00$ seperti disajikan pada Tabel 4, maka data kedua kelas dikatakan homogen.

Tabel 4 Tabel Uji Homogenitas

\begin{tabular}{|c|c|c|c|c|}
\hline Kelas & $\mathrm{N}$ & $F_{\text {hitung }}$ & $F_{\text {tabel }}$ & Keterangan \\
\hline Eksperimen & 24 & 1,2 & 2.00 & Homogen \\
\hline Kontrol & 24 & & & \\
\hline
\end{tabular}

Data berdistribusi normal jika $X_{\text {hitung }}^{2}<X_{\text {tabel }}^{2}$ pada taraf signifikan 5\%. Hasil perhitungann uji normalitas dan posttes pada kelas eksperimen menggunakan uji normalitas pada taraf signifikan $5 \%$ menunjukan bahwa $X_{\text {hitung }}^{2}=-12.73<X_{\text {tabel }}^{2}=11.07$ dan pada kelas kontrol di dapat nilai $X_{\text {hitung }}^{2}=-62.39<X_{\text {tabel }}^{2}=11.07$ (Tabel 5), maka data posttes kedua kelas dapat dikatakan terdistribusi normal. Nilai $X_{\text {tabel }}^{2}$ yang di tunjukan pada tabel dengan taraf signifikan $5 \%$ sesuai kriteria pengujian uji normalitas. 
Tabel 5 Uji Normalitas

\begin{tabular}{clccl}
\hline Kelas & $\mathrm{N}$ & $X_{\text {hitung }}^{2}$ & $X_{\text {tabel }}^{2}$ & Keterangan \\
\hline Eksperimen & 24 & -12.73 & 11.07 & Normal \\
\cline { 1 - 2 } Kontrol & 24 & & & \\
\hline
\end{tabular}

Berdasarkan hasil uji hipotesis pada taraf signifikan 5\% sesuai dengan kriteria pengujian hipotesis menunjukan bahwa jika $\boldsymbol{t}_{\text {hitung }}>t_{\text {tabel }}$ maka Ha diterima (Tabel 6). Hal ini berarti ada pengaruh model pembelajaran thinking alaud pair problem solving terhadap hasil belajar IPA Fisika siswa.

Tabel 6 Uji Hipotesis

\begin{tabular}{clccl}
\hline Kelas & $\mathrm{N}$ & $t_{\text {hitung }}$ & $t_{\text {tabel }}$ & Keterangan \\
\hline Eksperimen & 24 & 0.634 & 0.201 & Ha diterima \\
\hline Kontrol & 24 & & & \\
\hline
\end{tabular}

Berdasarkan hasil uji hipotesis pada taraf signifikan 5\% sesuai dengan kriteria pengujian hipotesis menunjukan bahwa jika $\boldsymbol{t}_{\text {hitung }}>t_{\text {tabel }}$ maka Ha diterima. Hal ini berarti ada pengaruh model pembelajaran thinking alaud pair problem solving terhadap hasil belajar IPA Fisika siswa.

Penelitian yang di laksanakan di SMPN 6 Praya Timur adalah penelitin quasi eksperimen yang bertujuan untuk mengetahui pengaruh model pembelajaran thinking alaud pair problem solving terhadap hasil belajar IPA Fisika siswa kelas VII pada materi getaran dan gelombang. Pelaksanaan pembelajaran di lakukan pada dua kelas yang di berikan perlakuan berbeda, yaitu kelas eksperimen mendapat perlakuan berupa model pembelajaran thinking alaud pair problem solving dan kelas kontrol tidak mendapat perlakuan atau tidak mengggunakan model pembelajaran thinking alaud pair problem solving.

Setelah menerapkan perlakuan yang berbeda pada kedua kelas selanjutnya di lakukan posttes untuk mengetahui pengaruh perlakuan yang di berikan terhadap hasil belajar IPA Fisika siswa pada materi getaran dan gelombang. Instrumen yang di gunakan berupa soal uraian yang telah di sesuaikan dengan indikator pembelajaran dan kemudian hasil posttes tersebut di analisis untuk mengetahui seberapa besar pengaruh perlakuan yang diterapkan serta untuk mengetahui hasil belajar fisika siswa.

Berdasarkan hasil posttes dari kedua kelas didapatkan nilai rata-rata kelas eksperimen 74,38 dengan katergori Baik dan kelas kontrol 71,90 dengan kategori Cukup Baik. Terlihat bahwa nilai rata-rata hasil belajar kelas eksperimen lebih tinggi dari kelas kontrol. Setelah menerapkan perlakuan yang berbeda pada kedua kelas selanjutnya di lakukan posttes untuk mengetahui pengaruh perlakuan yang di berikan terhadap hasil belajar IPA Fisika siswa pada materi getaran dan gelombang. Instrumen yang di gunakan berupa soal uraian yang telah di sesuaikan dengan indikator pembelajaran dan kemudian hasil posttes tersebut di analisis untuk mengetahui seberapa besar pengaruh perlakuan yang diterapkan serta untuk mengetahui hasil belajar fisika siswa.

Berdasarkan hasil posttes dari kedua kelas didapatkan nilai rata-rata kelas eksperimen 74,38 dengan katergori Baik dan kelas kontrol 71,90 dengan kategori Cukup Baik. Terlihat bahwa nilai rata-rata hasil belajar kelas eksperimen lebih tinggi dari kelas kontrol.

\section{KESIMPULAN}

Berdasarkan analisis data yang telah dilakukan dapat di simpulkan bahwa ada model pembelajaran thinking alaud pair problem solvingberpengaruh terhadap hasil belajar IPA Fisika siswa pada materi getaran dan gelombang.

\section{SARAN}

Guru IPA sebaiknya menerapkan model pembelajaran thinking alaud pair problem solving untuk meningkatkan hasil belajar IPA siswa. Dengan model siswa di latih untuk lebih aktif, dan mandiri untuk menyelesaikan masalah yang hadapi juga mampu membankit minat dan daya tarik siswa sehingga proses belajar menangajarpun tidak menonton dan membosankan. Bagi 
peneliti lain yang berminat untuk melaksankan penelitian dengan model pembelajaran thinking alaud pair problem solving untuk lebih pandai mengatur waktu agar hasil perlakuan betul - betul di rasakan oleh siswa sendiri.

\section{DAFTAR PUSTAKA}

Sugiyono. (2017). Statistika Untuk Penelitian. Bandung: Alfabeta

Hendrawan, A. (2014). Pengaruh Model Pembelajaran Problem Based Learning Terhadap Pemahaman Konsep Fisika. Mataram: FPMIPA IKIP Mataram

Awal. (2013). Penerapan Model Problem Based Learning Untuk Mengembangkan Aktivitas Berkarakter Dan Meningkatkan Hasil Belajar Siswa Kelas XI. Skripsi. Semarang : Universitas Negeri Semarang

Desryanti, Y. (2014). Pengaruh Metode Pembelajaran TAPPS Terhadap Kemampuan Penalaran Adaptif Matematika Siswa. Jakarta : Universitas Islam Negeri Syarif Hidayatullah

Puspitasari, N. (2015). Pengaruh Metode Pemecahan Masalah Terhadap Melalui Demontrasi Terhadap Hasil Belajar Fisika. Mataram: FPMIPA IKIP Mataram 